\title{
Serum Transferrin Receptors in Children with Hypochromic Microcytic Anaemia
}

\author{
Maria Aslam¹, Shahida Mohsin², Huma Amin³, Shabbir Hussain'2, Nisar Ahmed", \\ Ayesha Bhalli ${ }^{1}$ \\ ${ }^{1}$ Sharif Medical \& Dental College, Lahore, Pakistan \\ ${ }^{2}$ University of Health Sciences Lahore, Lahore, Pakistan \\ ${ }^{3}$ Fauji Foundation Medical College Rawalpindi, Lahore, Pakistan \\ ${ }^{4}$ Children Hospital and Institute of Child Health, Lahore, Pakistan \\ Email: ashas740@yahoo.com
}

Received 12 December 2013; revised 10 January 2014; accepted 17 January 2014

Copyright (C) 2014 by authors and Scientific Research Publishing Inc.

This work is licensed under the Creative Commons Attribution International License (CC BY).

http://creativecommons.org/licenses/by/4.0/

(c) (i) Open Access

\section{Abstract}

Hypochromic microcytic anaemia includes iron deficiency, anaemia of chronic disorders, beta thalassemia trait and sideroblastic anaemia. To rule out the cause of hypochromic microcytic anaemia is a diagnostic difficulty. The conventional laboratory tests used for diagnosis have few disadvantages. Serum transferrin receptor (sTfR) is the most reliable method for assessment of body iron. Eighty four children were included in this study. They were further divided into four groups: iron deficiency anaemia (IDA), anaemia of chronic disorders (ACD), beta thalassemia trait $(\beta$ TT) and controls. Children with IDA and ACD were diagnosed on the basis of history and serum iron profile. Subjects with $\beta$ TT had $\mathrm{HbA}_{2}>3.5 \%$. sTfR were performed on all subjects. Level of STfR in patients with IDA was $5.79 \mu \mathrm{g} / \mathrm{ml} \pm 1.3 \mu \mathrm{g} / \mathrm{ml}$. In patients with anaemia of chronic disorders (ACD), $\beta$ thalassemia trait and controls mean $\mathrm{sTfR}$ were $2.18 \mu \mathrm{g} / \mathrm{ml} \pm 0.6 \mu \mathrm{g} / \mathrm{ml}, 2.1 \mu \mathrm{g} / \mathrm{ml} \pm 0.5$ $\mu \mathrm{g} / \mathrm{ml}$ and $2.0 \mu \mathrm{g} / \mathrm{ml} \pm 0.5 \mu \mathrm{g} / \mathrm{ml}$ respectively. These results show level of $s$ TfR was raised in IDA when compared with controls or ACD and $\beta$ TT ( $p$ value $<0.001)$.

\section{Keywords}

Iron Deficiency Anaemia (IDA), Anaemia of Chronic Disorders (ACD), Serum Transferrin Receptors (sTfR)

\section{Introduction}

Hypochromic microcytic anaemia is characterized by decreased mean corpuscular volume (MCV) and mean 
corpuscular haemoglobin (MCH). Causes of hypochromic microcytic anaemia are iron deficiency anaemia (IDA), anaemia of chronic disorders (ACD), beta $(\beta$ ) thalassemia trait and sideroblastic anaemia. Iron deficiency is the most common cause of hypochromic microcytic anaemia in Pakistan [1]-[3].

Children with iron deficiency anaemia usually present with pallor, irritability, excessive crying, glossitis, systolic murmur, koilonychias, developmental and growth delay. Severe deficiency is related to lower intelligence quotient (I.Q) [4]. It may also impair psychomotor function, which causes mental retardation and decreased capability to learn. It also causes behavioral and cognitive delays [5]. Iron deficient children are inactive, less attentive, lethargic and hesitant [6] [7]. Anaemia of chronic disorders is seen in children having chronic inflammation, infection, malignancy or autoimmune disease [8].

Sideroblastic anaemia is a group of refractory anaemia that occurs due to mitochondrial iron overload in developing erythroid cells [9]. Beta thalassaemia trait occurs due to mild reduction of globin chain. Screening of $\beta$ thalassemia trait is done by red cell indices (MCV, MCH), hemoglobin and RBC count. Diagnosis is confirmed by electrophoresis which shows elevated $\mathrm{HbA}_{2}>3.5 \%$ [10] [11]. The conventional laboratory tests used for diagnosis of hypochromic microcytic anaemia include serum iron, total iron binding capacity (TIBC), serum ferritin and bone marrow iron studies. Serum iron decreases in both IDA and ACD. TIBC is increased in IDA while it is decreased in ACD [12] [13]. A considerable diagnostic overlap of serum iron and TIBC exists between IDA and normal children [14]. Serum ferritin can diagnose iron deficiency but it is an acute-phase reactant. Its level increases in inflammatory states and liver damage due to which its clinical interpretation is difficult. Its level decreases in IDA and increases in ACD [15] [16]. A definite diagnosis can be made by bone marrow examination with Prussian blue stain but it is painful and invasive procedure so it is should be avoided in children. It is also unacceptable to many patients [17].

Serum Transferrin receptors level is an indicator of iron deficiency, which helps in diagnosing coexistent iron deficiency in anaemia of chronic disorders and also helps in monitoring extent of erythropoiesis [18]. Iron requirement of cell regulates the number of receptors on the cells. sTfR is increased in case of decreased intracellular iron and it increases iron absorption [19]. Concentration of sTfR decreases in case of excess iron stored in the body. Its level is normal to low in ACD [20].

Patient with IDA, ACD and $\beta$ thalassaemia trait all present with hypochromic microcytic blood picture, therefore, it is necessary to differentiate between these anaemias by a specific test. Serum transferrin receptors are a reliable test for assessing body iron status and the degree of erythropoiesis in adults but no work has been done for assessment of sTfR as a diagnostic tool in children in Pakistan. Therefore this study was planned to determine the usefulness of sTfR levels in children of age 2 - 11 years presenting with hypochromic microcytic anaemias.

\section{Materials and Methods}

This study was conducted at Department of Haematology, University of Health Sciences, in collaboration with Children Hospital, Lahore. This work was done after obtaining permission from ethical committees of both institutes. Consent was taken from parents of children and history proforma was filled. It was a cross sectional comparative study. Consecutive sampling technique was used. It included 84 children aging 2 - 11 years with $\mathrm{Hb}<11 \mathrm{~g} / \mathrm{dl}$ for 2 to 5 years and $\mathrm{Hb}<11.5 \mathrm{~g} / \mathrm{dl}$ for $5-11$ years of age 14. They had low red cell indices (MCV $<75 \mathrm{fl}$ and $\mathrm{MCH}<25 \mathrm{pg}$ ). Patients on iron therapy or having recent transfusions were excluded.

Subjects were divided into four groups, each group included 21 children.

Group I comprised of patients with iron deficiency anaemia (IDA). Inclusion in this group was based on history and serum iron profile. Samples of patients presented in Pediatric OPD with history of lethargy, malaise, loss of appetite, excessive crying, progressive pallor, body aches, worm infestation or history of pica were taken. Serum iron, TIBC and serum ferritin were performed and children with serum iron $<60 \mu \mathrm{g} / \mathrm{dl}$, TIBC $>400$ $\mu \mathrm{g} / \mathrm{dl}$ and serum ferritin $<15 \mu \mathrm{g} / \mathrm{l}$ were diagnosed as patients of IDA and were included in this group. Any child with history of even mild infection or inflammatory condition was excluded from the study.

Group II included children with anaemia of chronic disorders (ACD). Patients with anaemia of chronic disorders had an underlying disease like pyrexia of unknown origin, respiratory infections (pneumonia and tuberculosis), chronic kidney infections and juvenile rheumatoid arthritis. These samples were obtained from children admitted in children hospital. Serum iron, TIBC and serum ferritin were performed. Children with serum iron < $60 \mu \mathrm{g} / \mathrm{dl}, \mathrm{TIBC}<250 \mu \mathrm{g} / \mathrm{dl}$ and serum ferritin $>120 \mu \mathrm{g} / \mathrm{l}$ were included in this group. 
Group III comprised of children with beta thalassaemia trait. Samples of Children with $\mathrm{HbA}_{2}>3.5 \%$ on HPLC were taken. They were siblings of $\beta$ thalassaemia major patients. Serum iron, TIBC and serum ferritin were performed. They have normal levels of serum iron, TIBC and serum ferritin. On the basis of serum ferritin children suffering beta thalassaemia and concomitant iron deficiency were excluded.

Control group (group IV) included normal healthy children with normal haemoglobin levels according to their age.

Complete blood counts (CBC) were done of all the samples on automated Hematology Analyzer Sysmex XT-1800i.

Serum iron and total iron binding capacity were performed spectrophometerically by using a commercially available kit of Randox on Metrolab 1600 at the wavelength of $560 \mathrm{~nm}$. Serum ferritin was done by using commercially available kit of Ferritin on Eciq Vitros Immunodiagnostic system.

Level of serum transferrin receptors was determined by quantitative sandwich enzyme immunoassay using commercially available kit which included the antibodies against the human Transferrin receptors. Measurements of absorbance were taken at wavelength $405 \mathrm{~nm}$ on automated ELISA plate reader.

\section{Statistical Analysis}

The data was analyzed using SPSS 16.0. The quantitative variables were expressed as mean \pm SD whereas the qualitative variables were reported as frequency and proportion. One way ANOVA (F-ratio) was performed to see the difference among four groups. Post Hoc test was also applied. A $p$ value of $\leq 0.05$ was considered as statistical significance.

\section{Results}

Eighty four children with mean age of 6.96 years \pm 3.0 years and male to female ratio of 1.6:1 were included in this study. Children with IDA presented with history of fatigue, malaise, lethargy, irritability, loss of appetite or worm infestation. In children with ACD an underlying disorder like chronic renal disease, pyrexia of unknown origin, juvenile rheumatoid arthritis, pneumonia or tuberculosis was present. Children with $\beta$ thalassemia trait presented with mild anaemia. Level of sTfR in the control group was $2.0 \mu \mathrm{g} / \mathrm{ml} \pm 05 \mu \mathrm{g} / \mathrm{ml}$ (range 1.0 - 2.95 $\mu \mathrm{g} / \mathrm{ml}$ ). Level of sTfR was increased in patients with IDA. Mean value was $5.7 \mu \mathrm{g} / \mathrm{ml} \pm 1.3 \mu \mathrm{g} / \mathrm{ml}$ and its range was $3.70-8.50 \mu \mathrm{g} / \mathrm{ml}$. After applying post hoc test statistically significant difference $(p<0.001)$ was observed when level of sTfR in IDA was compared with controls. Mean value of sTfR in ACD was $2.19 \mu \mathrm{g} / \mathrm{ml} \pm 0.6$ $\mu \mathrm{g} / \mathrm{ml}$ (range $0.75-2.95 \mu \mathrm{g} / \mathrm{ml}$ ). A significant difference $(p<0.001)$ was observed when compared with IDA while no statistical difference was noted when it was compared with the controls $(p>0.05)$. In patients with $\beta$ thalassemia trait mean \pm SD of sTfR was $2.14 \mu \mathrm{g} / \mathrm{ml} \pm 0.5 \mu \mathrm{g} / \mathrm{ml}$ and its range was $1.19-2.95 \mu \mathrm{g} / \mathrm{ml}$. When it was compared with IDA significant difference was noted $(p<0.001)$ but no significant difference was observed when compared with controls or ACD ( $p>0.05$ ). Figure 1 shows sTfR in different study groups. Level of sTfR in female and male controls was $2.0 \mu \mathrm{g} / \mathrm{ml}$ and $1.95 \mu \mathrm{g} / \mathrm{ml}$ respectively. No significance difference $(p=0.1)$ was observed when level of sTfR in female and male controls was compared. Level of sTfR in controls less than 6 years of age was compared with children of age more than 6 years. Mean level of sTfR in children of age less than 6 years was $2.0 \mu \mathrm{g} / \mathrm{ml}$ and in children of age more than 6 years it was $1.96 \mu \mathrm{g} / \mathrm{ml}$. No statistically significant difference was noted ( $p$ value $=0.1$ ). Mean level of haemoglobin, red cell indices $(\mathrm{MCV}, \mathrm{MCH}, \mathrm{MCHC})$, serum iron profile (serum iron, TIBC, serum ferritin) and serum transferrin receptors are given in Table 1.

\section{Discussion}

The common causes of hypochromic microcytic anaemia are iron deficiency and anaemia of chronic disorders. A diagnostic difficulty exists between these two anaemias. Several tests are used to assess the iron status of the patient. Use of multiple tests is less practical, so use of a single reliable test is an appropriate approach. In the present study, the diagnostic efficiency of sTfR as compared to other conventional laboratory tests was observed. Our study shows serum iron and TIBC are not useful for diagnosis of body iron status. A considerable overlap of these tests occurs in these two anemias. Comparable result was also reported in another study [21]. Serum iron has diurnal variations therefore sampling at specific time is required [16]. Furthermore, Serum iron and TIBC are not sensitive for diagnosing early iron deficiency, which are only helpful in diagnosis of advanced iron deficiency anaemia [17]. Serum ferritin is useful in diagnosis of body iron status but its role is limited because of its non specific in 


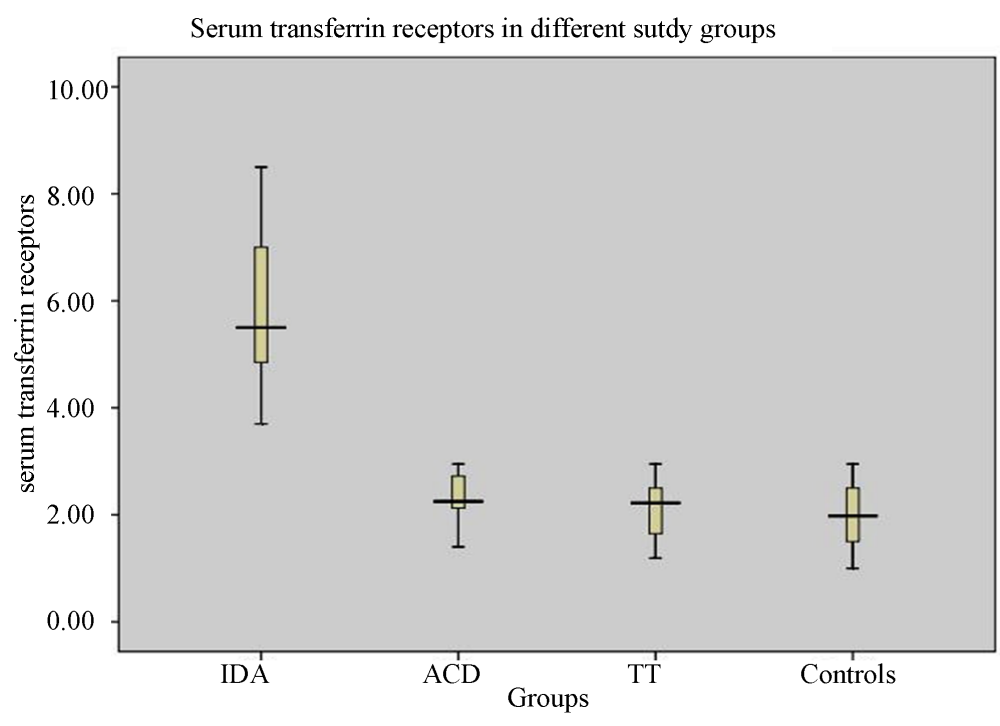

Figure 1. Box-plots for serum transferrin receptors in iron deficiency anaemia (IDA), Anaemia of chronic disorders (ACD), beta thalassemia trait (TT) and controls. IDA = Iron deficiency Anaemia. ACD = Anaemia of Chronic Disorder. $\mathrm{TT}=$ Thalassemia Trait.

Table 1. Levels of different parameters in IDA, ACD, $\beta$ TT \& Controls.

\begin{tabular}{ccccc}
\hline Parameter & IDA & ACD & $\boldsymbol{\beta}$ TT & Controls \\
\hline Hemoglobin (g/dl) & $9 \pm 0.9$ & $8.6 \pm 1.5$ & $10 \pm 0.4$ & $12 \pm 0.6$ \\
MCV (fl) & $67 \pm 5.7$ & $71 \pm 3.6$ & $74 \pm 1.7$ & $82 \pm 3.6$ \\
MCH (pg) & $20 \pm 3.8$ & $22 \pm 2.7$ & $24 \pm 1.6$ & $28 \pm 0.9$ \\
MCHC (g/dl) & $30 \pm 3.8$ & $31 \pm 2.4$ & $32 \pm 2.5$ & $33 \pm 1.9$ \\
Serum Iron ( $\mu \mathrm{g} / \mathrm{dl})$ & $43 \pm 8.9$ & $49 \pm 6.3$ & $96 \pm 17$ & $82 \pm 15$ \\
TIBC $(\mu \mathrm{g} / \mathrm{dl})$ & $470 \pm 63$ & $227 \pm 19$ & $300 \pm 43$ & $294 \pm 36$ \\
Serum Ferritin( $\mu \mathrm{g} / \mathrm{l})$ & $8.1 \pm 2.8$ & $506 \pm 322$ & $31 \pm 19$ & $50 \pm 31$ \\
sTfR $(\mu \mathrm{g} / \mathrm{ml})$ & $5.79 \pm 1.3$ & $2.18 \pm 0.6$ & $2.1 \pm 0.5$ & $2.0 \pm 0.5$ \\
\hline
\end{tabular}

Values are expressed as mean $\pm \mathrm{SD}$.

crease in liver damage and inflammatory diseases [22] [23].

Level of sTfR in controls was $1-2.9 \mu \mathrm{g} / \mathrm{ml}$. Mean value of sTfR in male and female controls was $2.0 \mu \mathrm{g} / \mathrm{ml}$ and $1.95 \mu \mathrm{g} / \mathrm{ml}$ respectively. No significance difference ( $p$ value $=0.1$ ) was observed when level of sTfR in female and male controls was compared. Other studies also showed that in healthy children no significant gender related difference was found in level of sTfR [24] [25]. Mean sTfR in controls of age less than 6 years was $2.0 \mu \mathrm{g} / \mathrm{ml}$ and in children more than 6 years of age, it was $1.96 \mu \mathrm{g} / \mathrm{ml}$. sTfR in these two control groups was compared and no statistically significant difference was noted $(p=0.1)$. These results showed that level of sTfR does not change with age in normal healthy population. Another study also showed similar results that level of sTfR does not vary with age and gender. In patients with IDA, ACD and beta thalassaemia trait level of sTfR depends on iron status so it has no direct relationship with age and gender in these patients [26].

We found increased level of sTfR in IDA as compared to controls $(p<0.001)$. A statistically significant difference $(p<0.001)$ was observed when sTfR level in IDA was compared with controls, ACD and $\beta$ thalassaemia trait. These results show an increase in sTfR which can diagnose IDA and it is the best marker to detect IDA as compared to serum iron, TIBC and serum ferritin. Comparable results were found in other studies [27] [28]. It can detect even patients of mild iron deficiency. Other studies also showed that it is more sensitive and reliable test to 
diagnose iron deficiency anemia and it can detect iron deficiency in earlier stage and even before the development of anaemia [29] [30].

In patients with ACD mean sTfR was $2.18 \mu \mathrm{g} / \mathrm{ml} \pm 0.6 \mu \mathrm{g} / \mathrm{ml}$ with a range of $0.75-2.95 \mu \mathrm{g} / \mathrm{ml}$. These results showed that $90.5 \%$ patients had normal sTfR levels and $9.5 \%$ with severe anaemia had decreased levels. In this study, level of sTfR was not raised in ACD while serum ferritin was increased. It is not affected by inflammatory process or infection as compared to serum ferritin. Other studies conducted on sTfR also showed that level of sTfR was not affected by infections, inflammations or liver disease [24] [31]. In this study we have seen increased levels of sTfR in IDA and normal or decreased levels in ACD. So increased level of sTfR can diagnose iron deficiency and it can differentiate between IDA and ACD. Another study conducted on sTfR showed that sTfR was helpful in diagnosing cause and degree of anaemia, evaluation of rate of erythropoiesis and monitoring the response of anaemic patient to therapy particularly before the changes in haemoglobin. Level of sTfR is significantly increased in IDA and remains normal in ACD, so it is useful in the differential diagnosis of microcytic anaemia [32]. It is a non invasive test, which requires small amount of serum and has no diurnal variations [33].

Another study conducted on sTfR showed that use of sTfR/ferritin ratio or sTfR/log ferritin ratio is also helpful in the differentiation of IDA and ACD [19]. In this study we found sTfR can diagnose IDA and ACD alone so there is no need to perform serum ferritin and calculate sTfR/ferritin ratio. Comparable results were observed in another study. According to that study level of sTfR was significantly increased in IDA with $100 \%$ sensitivity and specificity [17].

In this study, patients with $\beta$ thalassaemia trait had normal values of serum iron and TIBC. Level of serum ferritin was also in normal range but lower in these patients as compared to controls. sTfR was also in normal range in this group of patients $(1.19-2.95 \mu \mathrm{g} / \mathrm{ml})$. Therefore these tests can not diagnose $\beta$ thalassaemia trait. All thalassaemic patients included in this study had $\mathrm{HbA}_{2}>3.5 \%$ and diagnosis of $\beta$ thalassaemia trait was based on $\mathrm{HbA}_{2}$. Normal level of sTfR in $\beta$ thalassaemia trait has also been found in other studies [22]. $\mathrm{HbA}_{2}$ is a reliable test for differential diagnosis of $\beta$ thalassaemia trait and IDA [34] [35].

\section{Conclusion}

Level of serum transferrin receptors was significantly increased in iron deficiency anaemia so sTfR can diagnose IDA and it can differentiate between IDA and ACD. Level of sTfR does not change with age and gender in children.

\section{References}

[1] Coyer, M.S. (2005) Anaemia: Diagnosis and Management. Journal of Pediatric Health Care, 19, 380-385. http://dx.doi.org/10.1016/j.pedhc.2005.07.014

[2] Thomas, E.A. (2005) Investigation of Anaemia. Current Paediatrics, 15, 44-49. http://dx.doi.org/10.1016/j.cupe.2004.10.007

[3] Akhtar, F., Malik, S.H. and Anwar, M. (2002) Prevalence of Beta-Thalassaemia Trait in Patients with Hypochromic Microcytic Anaemia. Pakistan Journal of Pathology, 13, 11-13.

[4] Bogen, L.D., Duggan, K.A., Dover, J.G., et al. (2005) Screening for Iron Deficiency Anaemia by Dietary History in a High Risk Population. Pediatrics, 105, 1254-1258. http://dx.doi.org/10.1542/peds.105.6.1254

[5] Brotanek, M.J., Gosz, J., Weitzman, M., et al. (2007) Iron Deficiency in Early Childhood in the United States: Risk Factors and Racial/Ethnic Disparities. Pediatrics, 120, 568-575. http://dx.doi.org/10.1542/peds.2007-0572

[6] Lozoff, B., Corapci, F., Burden, M.J., et al. (2007) Preschool-Aged Children with Iron Deficiency Anaemia Show Altered Affect and Behavior. The Journal of Nutrition, 137, 683-689.

[7] Olney, K.D., Pollitt, E., Kariger, K.P., et al. (2007) Young Zanzibari Children with Iron Deficiency, Iron Deficiency Anaemia, Stunting, or Malaria Have Lower Motor Activity Scores and Spend Less Time in Locomotion. The Journal of Nutrition, 137, 2756-2762.

[8] Andrews, C.N. (2004) Anaemia of Inflammation: The Cytokine-Hepcidin Link. The Journal of Clinical Investigation, 113, 1251-1253. http://dx.doi.org/10.1172/JCI21441

[9] Alcindor, T. and Bridges, R.K. (2002) Sideroblastic anaemias. British Journal of Haematology, 116, 733-743 http://dx.doi.org/10.1046/j.0007-1048.2002.03378.x

[10] Rahim, F. and Keikhaei, B. (2009) Better Differential Diagnosis of Iron Deficiency Anaemia from Beta-Thalassaemia Trait. Turkish Journal of Hematology, 26, 138-145. 
[11] Mehta, B.C. (2002) Nestroft: A Screening Test for Beta Thalassaemia Trait. Indian Journal of Medical Sciences, 56, 537-544.

[12] Weiss, G. and Goodnough, T.L. (2005) Anaemia of Chronic Disease. The New England Journal of Medicine, 52, 1011-1023. http://dx.doi.org/10.1056/NEJMra041809

[13] Killip, S., Bennett, M.J. and Chambers, D.M. (2007) Iron Deficiency Anaemia. American Family Physician, 75, 671-678.

[14] WHO, UNICEF, UNU (2001) Iron Deficiency Anaemia: Assessment Prevention and Control. WHO, 33.

[15] Khan, S.A. and Shah, A.S. (2005) Iron Deficient Children and Significance of Serum Ferritin. The Journal of Pakistan Medical Association, 55, 420-423.

[16] Holmberg, L. (2000) Soluble Transferrin Receptor in the Diagnosis of Anaemia and Iron Deficiency in Childhood. Acta Paediatrica, 89, 1152-1153. http://dx.doi.org/10.1111/j.1651-2227.2000.tb00726.x

[17] Hanif, E., Ayub, M., Anwar, M., et al. (2005) Evaluation of Serum Transferrin Receptor Concentration in Diagnosing and Differentiating Iron Deficiency Anaemia from Anaemia of Chronic Disorders. The Journal of Pakistan Medical Association, 55, 13-16.

[18] Worwood, M. (2002) Serum Transferrin Receptor Assays and Their Application. Annals of Clinical Biochemistry, 39, 221-330. http://dx.doi.org/10.1258/0004563021902152

[19] Skikne, S.B. (2008) Serum Transferrin Receptor. American Journal of Hematology, 83, 872-875. http://dx.doi.org/10.1002/ajh.21279

[20] Williams, C.T., Maitland, K., Rees, D.C., et al. (1999) Reduced Soluble Transferrin Receptor Concentrations in Acute Malaria in Vanuatu. The American Journal of Tropical Medicine and Hygiene, 60, 875-878.

[21] Goyal, R., Das, R., Bambery, P. and Garewal, G. (2008) Serum Transferrin Receptors and Ferritin Index Shows Concomitant Iron Deficiency Anaemia and Anaemia of Chronic Disorders Is Common in Patients of Rheumatoid Arthritis in North India. Indian Journal of Pathology and Microbiology, 51, 102-104. http://dx.doi.org/10.4103/0377-4929.40417

[22] Jayaranee, S. and Sthaneshwar, P. (2006) Serum Soluble Transferrin Receptor in Hypochromic Microcytic Anaemia. Singapore Medical Journal, 47, 138-142.

[23] Leers, G.P.M., Keuren, W.F.J. and Oosterhuis, P.W. (2010) The Value of the Thomas-Plot in the Diagnostic Work Up of Anaemic Patients Referred by General Practitioners. International Journal of Laboratory Hematology, 32, 572-578. http://dx.doi.org/10.1111/j.1751-553X.2010.01221.x

[24] Feelders, R.A., Kramer, E.P. and Van, E.H.G. (1999) Structure, Function and Clinical Significance of Transferrin Receptors. Clinical Chemistry and Laboratory Medicine, 37, 1-10. http://dx.doi.org/10.1515/CCLM.1999.001

[25] Chouliaras, L.G., Premetis, E., Tsiftis, G., et al. (2009) Serum Transferrin Receptors: Distribution and Diagnostic Performance in Pre-School Children. Blood Cells, Molecules, and Diseases, 43, 163-168. http://dx.doi.org/10.1016/j.bcmd.2009.03.007

[26] Siddiqui, S.M. and Siddiqui, K.M. (2008) Public Health Significance of Iron Deficiency Anaemia. Pak Armed Forced Medical Journal, 58, 219-330.

[27] Choi, W.J. and Pai, H.S. (2003) Associations between Serum Transferrin Receptor Concentrations and Erythropoietic Activities According to Body Iron Status. Annals of Clinical \& Laboratory Science, 33, 279-284.

[28] Marković, M., Singh, M.N. and Subota, V. (2005) Usefulness of Soluble Transferrin Receptor and Ferritin in Iron Deficiency and Chronic Disease. Journal of Clinical \& Laboratory Investigation, 65, 571-576. http://dx.doi.org/10.1080/00365510500206542

[29] Lopez, V.A.M., Carracedo, A., Lendinez, F., et al. (2006) The Usefulness of Serum Transferrin Receptor for Discriminating Iron Deficiency without Anaemia in Children. Haematologica, 91, 264-265.

[30] Vendt, N., Talvik, T., Leedo, S., et al. (2009) The Reference Limits and Cut-Off Value for Serum Soluble Transferrin Receptors for Diagnosing Iron Deficiency in Infants. Journal of Laboratory Hematology, 31, 440-446. http://dx.doi.org/10.1111/j.1751-553X.2008.01060.x

[31] Chen, J.L., Li, S.L., Xu, M., et al. (2005) Clinical Significance of Serum Transferrin Receptor in Differential Diagnosis of Anaemia. Zhonghua Nei Ke Za Zhi, 43, 423-425.

[32] Beguin, Y. (2003) Soluble Transferrin Receptor for the Evaluation of Erythropoiesis and Iron Status. Clinica Chimica Acta, 329, 9-22. http://dx.doi.org/10.1016/S0009-8981(03)00005-6

[33] Cook, J.D., Skikne, B. S. and Baynes, R. D. (1993) Serum Transferrin Receptor. Annual Review of Medicine, 44, 63-74. http://dx.doi.org/10.1146/annurev.me.44.020193.000431

[34] Madan, N., Sikka, M. and Sharma, S. (1998) Haematological Parameters and $\mathrm{HbA}_{2}$ Levels in Beta-Thalassaemia Trait 
with Coincident Iron Deficiency. Indian Journal of Pathology and Microbiology, 41, 309-313.

[35] Demir, A., Yarali, N., Fisgin, T., Duru, F. and Kar, A. (2002) Most Reliable Indices in Differentiation between Thalassaemia Trait and Iron Deficiency Anaemia. Pediatrics International, 44, 612-616.

http://dx.doi.org/10.1046/j.1442-200X.2002.01636.x 